\title{
Natural resources and violent conflict: resource abundance, dependence, and the onset of civil wars
}

\author{
By Christa N. Brunnschweiler ${ }^{\star}$ and Erwin H. Bulte†
}

${ }^{*}$ CER-ETH Center of Economic Research at ETH Zurich, Switzerland, and OxCarre, University of Oxford; e-mail: cbrunnschweiler@ethz.ch $\uparrow$ Development Economics Group, Wageningen University, De Leeuwenborch, Hollandseweg 1, 6706 KN Wageningen, and Department of Economics, Tilburg University, Netherlands; e-mail: Erwin.bulte@wur.nl

\begin{abstract}
In this paper we examine the claim that natural resources invite civil conflict, and challenge the main stylized facts in this literature. We find that the conventional measure of resource dependence is endogenous with respect to conflict, and that instrumenting for dependence implies that it is no longer significant in conflict regressions. Instead, it appears that conflict increases dependence on resource extraction (as a default sector). Moreover, resource abundance is associated with a reduced probability of the onset of war. These results are robust to a range of specifications and, considering the conflict channel, we conclude there is no reason to regard resources as a general curse to peace and development.
\end{abstract}

JEL classifications: Q34, O11, N40, N50.

\section{Introduction}

The appreciation for natural resources as a driver of economic development has undergone a dramatic change in the past decades. While economists generally perceived an abundance of resources as advantageous until the 1980s, an influential empirical and theoretical literature emerged in the 1990s that reached rather opposite conclusions. The phrase 'natural resource curse' was coined and, perhaps because of its paradoxical connotation, caught on in both academic and policy circles. The current literature distinguishes between no less than three different 'dimensions' of the resource curse: resources are associated with (i) slower economic growth, (ii) violent civil conflict, and (iii) undemocratic 
regime types. ${ }^{1}$ Arguably, these different manifestations of the curse can be inter-related.

In this paper we focus on the nature of the relation between resources and civil war. Collier and Hoeffler (1998) offered a pioneering empirical contribution based on cross-section analysis, where among other things they found that resource dependence had a significant curvilinear effect on both the onset and duration of war. As a measure of resources they used the ratio of primary exports to GDP - a measure also popularized by Sachs and Warner (1997) in the parallel literature focusing on the relation between resources and economic growth. In a follow-up series of papers, Collier and Hoeffler demonstrated (i) that resources have an impact on some types of wars, but not on others (see also Reynal-Querol, 2002); (ii) that resources are also significantly correlated with the onset of war in a panel-data setting (Collier and Hoeffler, 2004); and finally (iii) that the main results are robust to employing alternative measures of resource wealth (notably a measure of resource rents, see Collier and Hoeffler, 2005).

This series of papers has proved influential and controversial, not least because of its focus on the economic roots of conflict. By now, the standard explanations of civil war advanced by economists and political scientists are 'greed' and 'grievance'. ${ }^{2}$ The rational choice paradigm considers civil war a special form of noncooperative behavior, and the greed motive simply reflects opportunities for rebels (or rebel leaders) to enrich themselves. Grievance, in contrast, is rooted in a behavioral paradigm, and emphasizes relative deprivation, social exclusion and inequality (e.g., due to ethnic or religious divides, see Regan, 2003). In the context of resource-rich societies, grievance might be exacerbated by insufficiently compensated land expropriation, environmental degradation, inadequate job opportunities, and labour migration (e.g., Rosser, 2006). Resource rents also provide a potential source of funding for the start-up costs associated with initiating a rebel organization. The Collier and Hoeffler paradigm views rebels as rational predators or, using terms with a less negative connotation, as entrepreneurs following up on a profitable opportunity. The theoretical underpinnings of this perspective may be traced back to Grossman (1991) and Hirschleifer (1995).

\footnotetext{
${ }^{1}$ We cannot possibly do justice to the many papers in these three fields, but selected contributions include the following works. On economic growth, refer to Sachs and Warner (1997), Mehlum et al. (2005), but also Brunnschweiler and Bulte (2008) and the citations therein. On conflict, refer to Collier and Hoeffler $(1998,2004)$, Ross (2004a,b), Collier et al. (2009), Lujala (2009), and to the special issue of the Journal of Conflict Resolution devoted to the topic. On regime type (and institutions more broadly), refer to Ross (2001), Leite and Weidmann (2002), Jensen and Wantchekon (2004), and Bulte et al. (2005). Overview articles include Rosser (2006) and van der Ploeg (2009).

${ }^{2}$ Ballantine (2003) has noted that the mix of greed and grievance can be particularly potent, and relevant as an explanation of the onset of war. Ross (2004b) examines the greed and grievance motives, along with other possible conflict triggers, in a series of case studies. Other reasons why resources might be linked to conflict have to do with the probability of foreign intervention (Rosser, 2006) and the probability of suffering from economic shocks (e.g., Collier and Hoeffler, 2005).
} 
A small 'cottage industry' has now emerged in economics and political science on the purported association between natural resources and civil war (Ross, 2004a; Ron, 2005), and the resource-war link is increasingly viewed as a stylized fact. However, this link, and in particular the economic terms within which it has been couched, has not gone unchallenged. The first series of challenges stems from doubts about the data and statistical analysis. If resources are important for financing an insurgence, then arguably the 'lootability' of resources is important. If so, many resources included in the standard dependence variable are irrelevant. Worse: some relevant resource revenues-such as those obtained by smuggling - are not included in the data. In contrast, if future resource rents are a motive for rebellion (the prize that may be grabbed after seizing power), then a wider range of resources might be relevant. Similarly, lumping all types of conflict together may obscure the analysis (Le Billon, 2001).

The empirical evidence is mixed (e.g., Elbadawi and Sambanis, 2002; Ross, 2004a, 2006). Ross (2003) finds little support for a link in general, but does argue in favour of a relation between conflict and 'lootable' resources such as alluvial diamonds and drugs (see also Snyder and Bhavnani, 2005; Olsson, 2006). Lujala et al. (2005) demonstrate that there is no relation between diamonds and conflict onset, but that lootable (alluvial) and non-lootable (i.e underground) diamonds have opposite effects on the incidence of conflict. De Soysa (2002), Fearon (2005), Ross (2006), De Soysa and Neumayer (2007), and Lujala (2009) emphasize the role of (legal) oil and mineral resource trading in explaining conflict, but this is disputed by Smith (2004). Humphreys (2005) suggests dependence on agricultural production matters, implying that social relations co-shaped by economic structure are a driver of conflict.

A second challenge concerns the economic perspective on (potential) rebels as the key decision maker. ${ }^{3}$ Many analysts favour explanations based on politics and 'state strength' over explanations based on economics (e.g., Auty, 2004; Dunning, 2005; Humphreys, 2005; Snyder and Bhavnani, 2005). According to this view, resource-rich economies tend to suffer from weak and unaccountable leadership, which is unable or unwilling to diversify the economy and deliver key public goods. Alternatively, resource riches may invite oppressive regimes, resulting in genuine grievances among a share of the population.

It is not always easy to distinguish between the various mechanisms linking resources to war. For example, while the level of income may serve as a proxy for the opportunity cost of rebel activity entering in an economic analysis, one may also argue that it proxies for the 'effectiveness of the state' in delivering public goods (e.g., Fearon and Laitin, 2003).

\footnotetext{
${ }^{3}$ Recent literature also supports the rational-rebel or greed explanation. For example, Lujala (2009) finds that the exact location of resource endowments (in the war zone or not) matters for conflict duration, and that the onset of conflict is affected by onshore but not by offshore oil extraction. These results suggest that the effect of resources on rebels' opportunity and incentives may be more important than the effect on state revenues and capacity.
} 
Is this literature moving towards a consensus? If so, the pace of convergence is very slow. Complicating matters further, there is a literature that implicates resource scarcity, rather than abundance, as a driver of violent conflict (e.g. Homer-Dixon, 1999). Scarcity is linked to conflict via two mechanisms: it may trigger marginalization of powerless groups by an élite scrambling for resources, and it could have a debilitating effect on processes of social and economic innovation (resulting in an 'ingenuity gap'). In the words of Hirschleifer (1995, p.44): 'As Malthusian pressures depress per capita incomes, it comes to a choice between fighting and starving'.

The contribution of this paper is twofold. First, we explore the nature of the causal link between resources and the onset of war, and provide the first attempt in this literature to instrument for resource dependence in a two-stage procedure. ${ }^{4}$ While the literature refers to the conventional 'ratio of primary exports to GDP' variable as both a measure of resource dependence and abundance, it is evident that it is at best an imperfect proxy for the latter. Resource-rich countries that have also developed other industries may not be dependent on primary exports. Similarly, resource-poor countries might nonetheless depend on primary production if they host few alternative economic activities. Our key concern is that this resource variable may be endogenous with respect to conflict (see also De Soysa, 2002; Dunning, 2005; Lujala et al., 2005; Ross, 2006; Murshed and Tadjoeddin, 2007; and Lujala, 2009). ${ }^{5}$

A similar concern applies to analyses based on scaled resource rents (rents divided by national income), as in Collier and Hoeffler (2005) and De Soysa and Neumayer (2007). If investments in sectors other than the resource-agricultural complex are depressed by either past, present, or (the shadow of) future conflict, then the nature of the resource-war link could run from conflict to resource dependence, rather than the other way around. Investment in manufacturing requires a stable politico-economic environment, and one may hypothesize that the resource sector is less sensitive to mounting tensions or outright conflict than other sectors. ${ }^{6}$ Reasons for this may include limited linkages with the rest of the economy, the sector's orientation towards international markets, and its inability to relocate. Moreover, as argued by Ross (2004a, p.338): 'using lagged independent variables does not eliminate the danger of reverse causality: civil wars can be preceded by years of low-level violence that drives off manufacturing firms, producing a high level of resource dependence before the violence actually begins'.

\footnotetext{
${ }^{4}$ We do not consider the relation between resources and conflict duration or intensity. For more work on these issues, refer to Doyle and Sambanis (2000), Ballantine (2003), Ross (2003, 2004b), and Fearon (2004).

${ }^{5}$ In the resources-growth literature, this point has been made by Ding and Field (2005), Arezki and van der Ploeg (2007), and Brunnschweiler and Bulte (2008).

${ }^{6}$ Lujala (2009) even mentions that (the shadow of future) conflict might increase resource extraction (and hence: dependence) as it gives incumbent leaders an incentive to increase extraction to finance investments in the military, or for personal gain.
} 
By instrumenting for resource dependence, we test whether it is causally linked to conflict.

Second, we add a proxy for resource abundance-a stock variable capturing the discounted value of the future flow of resource rents-in our empirical analysis, and explore the relation between resource wealth and the onset of conflict anew. Our variable naturally captures many of the interpretations associated with the alleged resource-war link. For example, to the extent that conflicts are triggered by greed (fighting over future resource rents), our variable better captures the essence of what is at stake than measures of current dependence. We consider the nature of the impact of abundance on conflict, and we test whether resource abundance affects conflict directly, or that its effect is indirect-via income and resource dependence.

Our main findings turn received wisdom upside down. We find that resource dependence is indeed an endogenous variable in conflict regressions, and that properly accounting for this endogeneity removes the positive statistical association between dependence and conflict onset. We also demonstrate that a country's history with respect to war and peace is a significant determinant of resource dependence-clenching our main result. Moreover, we find a significant negative (indirect) relationship between resource abundance and the onset of war, probably because of an income effect. This suggests the label 'resource curse' may be misplaced. Resource-rich countries have on average a lower propensity to enter a civil war, but countries that do end up with civil strife (possibly even resourcepoor ones) will experience increasing dependence on the primary sector.

\section{Data and empirical strategy}

We now outline our empirical procedure and present the most important data. Following up on the empirical strategy by Brunnschweiler and Bulte (2008), we first explore the determinants of resource dependence, extending the analysis of Collier and Hoeffler (2004) to a panel dataset of nine 5-year periods between 1960-2004 (1960-4, 1965-9, etc.). ${ }^{7}$ We then proceed by analysing the impacts of resource dependence as well as abundance on the propensity of the onset of conflict. Our main resource abundance stock variable may directly affect the probability of conflict (through rebellion motives), but the influence may also be indirect through resource dependence or income.

We run three different regression equations-a resource dependence equation, an income equation, and a conflict regression equation. The first regression is important to assess whether resource dependence $R D$ (denoted by $\operatorname{sxp}$ or $\ln s x p$ in the tables, calculated as primary exports divided by GDP at the start of each period)

\footnotetext{
${ }^{7}$ Fearon (2005) demonstrates that the results of Collier and Hoeffler are not robust to using annual panel data. However, it is not evident that annual data better capture the potentially 'slow dynamics' that may trigger the onset of war.
} 
is a proper exogenous variable in conflict regressions, as implicitly assumed until now. Specifically, we try to unravel the determinants of resource dependence as follows:

$$
R D(t i)=a_{0}+a_{1}{ }^{*} \text { conditioning variables }(t i)+a_{2}{ }^{*} R A(t i)+e,
$$

where $R A$ measures resource abundance in period $t$ in country $i$, and $e$ is an error term. An analogous regression is run with (log) per capita income levels $(\operatorname{lng} d p)$ as the dependent variable, as income may be endogenous as well.

$R A$ is included to account for the notion that resource-rich economies may have a comparative advantage in exporting primary products (in the resource dependence regression), or that resources may have an income effect via sales or access to foreign credit (in the case of the income regression). We use estimates of the net present value of rents (in USD per capita) of a country's total natural capital stock, taking the natural logarithm of the value to reduce the influence of outliers (denoted as innatcap). The aggregate measure includes subsoil assets (fuel and non-fuel minerals), cropland, pastureland, timber and nontimber forest resources, and protected natural areas. We also consider two disaggregate measures, focusing on fuel and non-fuel mineral resources (Insubsoil) and land (Inland, including crop- and pastureland, protected areas, and forest resources) separately. All these $R A$ estimates are taken from extensive studies by the World Bank (1997, 2006), and we refer to World Bank (1997, ch.3) for details about the computation of the net present values. Drawbacks of the variables are their limited country and time coverage: they are available for around 100 countries, and only two years (1994 and 2000). ${ }^{8}$

It can be argued that resource abundance is a relatively persistent variable. However, to test the robustness of our results, we also use alternative measures of resource abundance, namely per capita estimates of the value of total reserves of fuel and non-fuel minerals (including industrial diamonds) in 1970 from Norman (2009), and the per capita production and reserves of oil from 1960-99 from Humphreys (2005). Both datasets cover a wider range of countries, bringing the sample coverage up to 115 and 118 countries, respectively, albeit at the cost of omitting all non-mineral natural resources from the analysis.

How 'exogenous' are our resource abundance measures? We argue that the data on natural resource abundance are likely to be relatively independent of local issues (including conflict intensity), and therefore exogenous for our purpose. The (fuel and non-fuel) mineral deposits have been well explored and estimated due to the potentially large profits they present, and thanks to the involvement of large multinational firms who operate with little regard for local political or technological conditions. Of course, our resource abundance data are not perfect,

\footnotetext{
${ }^{8}$ We chose to use the 1994 values for the periods until 1999, and the 2000 values for the last period from 2000-2004. All our results are robust to using only the earlier or later data throughout the sample period.
} 
as the present value of rents is not completely invariant with respect to policies, and exploration and exploitation efforts may to some extent be determined by the level of development. But we believe they are less prone to the policy endogeneity, which plagues export-based and rent-based dependency measures; and less subject to technology standards, which influence production levels (see also Brunnschweiler and Bulte, 2008). For example, the World Bank resource abundance measures are not highly correlated with years of schooling, which is a common proxy for technology levels. ${ }^{9}$ In addition, they offer the advantage of potentially covering all natural resources in the estimation. However, in light of the simple observation that resource stock estimates may be both greater or smaller in conflict-prone environments (when historic extraction rates have been decelerated or accelerated), it is evident that the appropriateness of stocks as instruments is an empirical issue. Hence, in what follows we formally test our hypothesis that stock variables are exogenous, and we consistently find support for this hypothesis. ${ }^{10}$

We have several conditioning variables serving as exogenous instruments in eq. (1). Instrumental variables should be exogenous and correlated with the $1^{\text {st }}$ stage endogenous variables (eq. (1)), but not with the error term of the $2^{\text {nd }}$ stage conflict regression (eqs (2) and (2') below). Theory offers some guidance that these conditions are satisfied. Our first instruments are three geographical variables-latitude, \% of land area in the tropics (tropics), and distance to the nearest coast or navigable river (distcr). The relation between these instruments and income has been elaborated by Sachs (2003) and others. It is also evident that biophysical conditions can affect a country's comparative advantage in exporting primary commodities (and hence its resource dependence). Moreover, there is no indication that these instruments invite conflict directly and therefore correlate with the $2^{\text {nd }}$ stage error term: the geophysical feature most commonly found to influence conflict is the degree of mountainousness (see below), which is not directly linked to our geographical instruments. Similarly, geopolitical interests are not captured by our variables.

A further instrument is given by the average openness to trade over the previous five-year period (openness). While the openness variable (imports + exports/GDP) is both an outcome of trade policy and economic development as well as a determinant thereof, and could therefore be endogenous with respect to income and resource dependence, our statistical analysis clearly demonstrates that we may use this variable as an instrument. Furthermore, there is little reason to suspect that

\footnotetext{
${ }^{9}$ E.g., the correlations between years of schooling in 1970 and the $(\log$ of $)$ subsoil wealth are 0.38 for 1994 and 0.35 for the 2000 measure, while for the (log of) natural capital measure the correlations are 0.53 (1994) and 0.48 (2000).

${ }^{10} \mathrm{~A}$ further issue regarding the resource abundance measures is measurement error, which may be introducing some amount of 'noise' into the data. However, measurement error can reasonably be expected to increase the standard error, and therefore bias the significance level of the abundance variables downward, which would not be in favour of our argument.
} 
openness to trade has a direct effect on conflict potential. Finally, we use a dummy variable for a presidential-type system of government (presidential), based on seminal contributions by Persson and Tabellini (2003), who argued that constitutional designs affect the accountability and representativeness of the executive. Specifically, presidentialism is associated with spending for special interests - including the interests of the primary sector-at the expense of general (more growth-inducing) public goods, because the incumbent decision maker does not depend on a stable majority among the legislators as in a parliamentary system. Presidentialism is therefore expected to positively affect resource dependence, and conceivably also have a negative impact on income, while there is no evidence that one system leads to more incidents of civil war than the other.

Equation (1) thus captures the fact that resource dependence may be influenced by both the biophysical context (resource abundance and geography), and by the institutional framework and the policy choices it generates (government system and trade openness). As mentioned above, since we don't wish to rule out a priori that something similar applies to our income variable, we also run a series of regressions akin to (1) but with income $I$ (i.e. the log of GDP per capita at the start of each period, $\operatorname{lng} d p$ ) as the dependent variable (see also Collier et al., 2009).

Our main challenge is to examine the impact of resource dependence $(R D)$ and abundance $(R A)$ on the propensity of conflict to start, both directly and indirectly (for the case of abundance). To this end, we compare the results of pooled instrumental variable (IV) probit and panel data IV regression analyses with those of simple probit regressions. The final equation is thus:

$$
\begin{aligned}
\text { warstart }(t i)= & b_{0}+b_{1}{ }^{*} \text { conditioning variables }(t i)+b_{2}{ }^{*} R D(t i) \\
& +b_{3}{ }^{*} I(t i)+b_{4}{ }^{*} R A(t i)+v,
\end{aligned}
$$

where warstart is a dummy that takes on value zero if conflict did not occur during the period, and a value of one otherwise. $v$ is an error term and $I$ represents income. It is an open question whether resource abundance has any discernable direct effect on the onset of war when accounting for the indirect effects (i.e. via resource dependence and income). In case our two stage regression model suggests it does not, we continue instead by estimating a simplified model in the $2^{\text {nd }}$ stage:

$$
\text { warstart }(t i)=c_{0}+c_{1}{ }^{*} \text { conditioning variables }(t i)+c_{2}{ }^{*} R D(t i)+c_{3}{ }^{*} I(t i)+\varepsilon \text {. }
$$

We treat ongoing conflicts as missing observations so as not to confuse the onset of war with its duration, adding the number of peaceful years as a control variable. We base our definition of civil war on the Correlates of War (COW) database by Gleditsch (2004), which considers all organized military conflicts with at least 1000 battle-related deaths, of which at least 5\% must be inflicted by the weaker party. Furthermore, at least one party in the conflict must be the national government. This definition gives us a potential sample of over 160 countries and up to 93 conflict episodes between 1960-2004. In the robustness tests, we also code ongoing conflicts as zero and introduce a dummy variable for 
conflict in the previous period, following the methodology of Fearon and Laitin (2003). Furthermore, we consider an alternative definition of conflict based on the Armed Conflict Database (ACD) compiled by Gleditsch et al. (2002). The ACD classifies conflicts according to two main dimensions, the first being location and participants: 1 . extra-systemic conflicts, 2. interstate wars, 3. intrastate wars, and 4. internationalized intrastate wars, of which we include all but interstate wars. The second dimension is the level of violence: both minor conflicts (more than 25 battle-related deaths per year, at least 1000 deaths over the entire conflict) and major conflicts (more than 1000 battle-related deaths per year, analogous to the COW classification) are included, bringing the potential coverage in our sample to 149 conflict episodes. Further details on all variables and sources are given in the Appendix.

Equation (2) allows us to distinguish between different interpretations of the resource-war link. If resource dependence (or abundance) exacerbates the risk of conflict, then coefficients $b_{2}$ (or $b_{4}$ ) should take on a significant and positive value. To gauge the total effect of resource abundance on conflict, one needs to account for both the (possible) direct effect (measured by $b_{4}$ ), and the indirect effect via dependence or income (obtained by combining $b_{2}$ and $b_{3}$ ). For negative values of $b_{2}$ and $b_{3}$, i.e. for sufficiently large offsetting indirect effects, the conventional interpretation of the resource-war link needs revision.

The conditioning variables include a wide set of explanatory variables used in the literature: the average annual GDP per capita growth over the previous period (growth); the years of peace since the last conflict (or WWII) as mentioned above; the social fractionalization measure (socialfrac) from Collier and Hoeffler (2004); the (natural $\log$ of) population at the beginning of the period (Inpop); \% of mountainous terrain (mountain) from Fearon and Laitin (2003); and a dummy variable for former French colonies in sub-Saharan Africa during 1960-99 (frafcol, see Collier et al., 2009). We also add a political regime measure from the Polity IV project (polity), ranging from -10 (strong autocracy) to 10 (strong democracy), as well as the proportion of young men aged 15-29 in the total population (youngmenpop, taken from various issues of the UN Demographic yearbook), to reflect the potential recruitment base for rebel movements (see Collier et al., 2009). Table 1 shows the descriptive statistics of the main variables.

\section{Regression results and robustness analysis}

We now present our empirical results. In the first two columns of Table 2 (Panel A) we derive results that are very similar to existing work. Specifically, we obtain a (weakly) concave relationship between resource dependence and the onset of conflict in column (1), in the sense that resource dependence initially leads to a higher probability of conflict, but then in fact decreases the probability. Note that the coefficient on the squared term, $\operatorname{sxp2}$, is insignificant. However, we find that the logarithmic specification using $\operatorname{lns} x p$ in column (2) highlights the correlation most clearly and robustly (see Fearon, 2005), and in what follows we 
Table 1 Descriptive statistics

\begin{tabular}{lccc}
\hline & Sample & $\begin{array}{c}\text { Peaceful } \\
\text { episodes }\end{array}$ & $\begin{array}{c}\text { Conflict } \\
\text { episodes }\end{array}$ \\
\hline Warstart & 0.071 & 0 & 1 \\
s.d. (obs) & $0.257(1311)$ & $0(1218)$ & $0(93)$ \\
Years of peace since last conflict & 28.851 & 29.725 & 17.41 \\
s.d. (obs) & $15.177(1311)$ & $14.834(1218)$ & $15.056(93)$ \\
GDP per capita (USD) (in logs) & 8.235 & 8.344 & 7.473 \\
s.d. (obs) & $1.135(1211)$ & $1.128(1062)$ & $0.823(74)$ \\
GDP growth in previous period & 1.418 & 1.647 & 0.017 \\
s.d. (obs) & $3.38(1130)$ & $3.103(995)$ & $4.928(64)$ \\
Total primary export share of GDP & 0.165 & 0.176 & 0.142 \\
s.d. (obs) & $0.183(1311)$ & $0.191(1190)$ & $0.116(86)$ \\
Total natural capital (USD per capita, & 8.441 & 8.497 & 7.868 \\
$\quad$ in logs) & & & \\
s.d. (obs) & $0.951(821)$ & $0.964(733)$ & $0.630(41)$ \\
Oil production per capita & 0.0418 & 0.047 & 0.0142 \\
s.d. (obs) & $0.2845(1104)$ & $0.2845(943)$ & $0.0376(77)$ \\
Oil reserves per capita & 0.7513 & 0.8574 & 0.1512 \\
s.d. (obs) & $6.8045(1119)$ & $7.3567(955)$ & $0.5467(80)$ \\
Value of minerals in 1970 & 27.5116 & 31.0021 & 5.0909 \\
$\quad$ (USD per capita) & & & \\
s.d. (obs) & $159.0941(1230)$ & $170.112(1072)$ & $11.0884(76)$ \\
\hline
\end{tabular}

use the log of the share of primary exports in income as our key resource dependence variable.

The coefficients for the other variables are also in line with previous research. We find a negative correlation between the onset of war on the one hand, and income, income growth, the duration of peace, and the French colony dummy on the other hand. There is a positive correlation between population size and the propensity of war. The percentage of young men, the variable measuring mountainous area, the political system (polity), and social fractionalization appear to have no correlation with civil war.

In column (3) we introduce our aggregate resource abundance variable. It enters with a significant and negative coefficient-countries with more abundant natural capital appear to have a lower probability of becoming engaged in civil war. This result holds when we run a logit estimation adjusted for the 'rare event' nature of civil war, as shown in Table 4, column (1). If correct and robust, this result turns the 'resource curse' interpretation upside down.

Two other effects stand out. First, the resource dependence variable $(\ln s x p)$ is no longer significant when controlling for abundance. Second, both the significance level and coefficient value of the income variable are attenuated. Specifically, income is now only significant at the $10 \%$ level, and the value of its coefficient drops from -0.39 to -0.27 . This could be indicative of collinearity between income and resource abundance. Moreover, in light of our earlier arguments, there is 
Table 2a Civil war onset

\begin{tabular}{|c|c|c|c|c|c|c|}
\hline & $\begin{array}{c}(1) \\
\text { probit }\end{array}$ & $\begin{array}{c}(2) \\
\text { probit }\end{array}$ & $\begin{array}{c}(3) \\
\text { probit }\end{array}$ & $\begin{array}{c}(4) \\
\text { ivprobit }\end{array}$ & $\begin{array}{c}(5) \\
\text { ivprobit }\end{array}$ & $\begin{array}{c}(6) \\
\text { ivprobit }\end{array}$ \\
\hline $\operatorname{sxp}$ & $\begin{array}{c}3.185 \\
(1.72)^{\star}\end{array}$ & & & & & \\
\hline $\operatorname{sxp} 2$ & $\begin{array}{l}-3.382 \\
(-0.99)\end{array}$ & & & & & \\
\hline $\operatorname{lnsxp}$ & & $\begin{array}{c}0.231 \\
(2.31)^{\star *}\end{array}$ & $\begin{array}{c}0.129 \\
(0.97)\end{array}$ & $\begin{array}{l}-0.083 \\
(-0.35)\end{array}$ & $\begin{array}{c}-0.1 \\
(0.38)\end{array}$ & $\begin{array}{l}-0.068 \\
(-0.24)\end{array}$ \\
\hline lnnatcap & & & $\begin{array}{l}-0.285 \\
(2.05)^{\star *}\end{array}$ & & & \\
\hline $\operatorname{lngdp}$ & $\begin{array}{l}-0.372 \\
(3.37)^{\star * *}\end{array}$ & $\begin{array}{l}-0.386 \\
(3.47)^{\star * *}\end{array}$ & $\begin{array}{c}-0.267 \\
(1.84)^{\star}\end{array}$ & $\begin{array}{l}-0.753 \\
(3.20)^{\star * *}\end{array}$ & $\begin{array}{l}-0.788 \\
(2.72)^{\star \star *}\end{array}$ & $\begin{array}{l}-0.75 \\
(2.88)^{\star * *}\end{array}$ \\
\hline growth & $\begin{array}{l}-0.071 \\
(3.07)^{\star * *}\end{array}$ & $\begin{array}{l}-0.071 \\
(3.05)^{\star * *}\end{array}$ & $\begin{array}{l}-0.105 \\
(2.77)^{\star * *}\end{array}$ & $\begin{array}{l}-0.079 \\
(1.96)^{* *}\end{array}$ & $\begin{array}{c}-0.105 \\
(1.96)^{\star}\end{array}$ & $\begin{array}{l}-0.08 \\
(1.93)^{\star}\end{array}$ \\
\hline $\operatorname{lnpop}$ & $\begin{array}{l}0.153 \\
(2.77)^{\star * *}\end{array}$ & $\begin{array}{l}0.167 \\
(2.89)^{\star * *}\end{array}$ & $\begin{array}{c}0.128 \\
(1.68)^{\star}\end{array}$ & $\begin{array}{r}0.111 \\
(1.02)\end{array}$ & $\begin{array}{c}0.112 \\
(0.79)\end{array}$ & $\begin{array}{c}0.111 \\
(0.93)\end{array}$ \\
\hline socialfrac & $\begin{array}{c}-0.0001 \\
(1.07)\end{array}$ & $\begin{array}{c}-0.0001 \\
(1.11)\end{array}$ & $\begin{array}{l}0 \\
(0.69)\end{array}$ & $\begin{array}{l}-0.0001 \\
(-0.98)\end{array}$ & $\begin{array}{l}-0.00002 \\
(-0.25)\end{array}$ & $\begin{array}{l}-0.0001 \\
(-0.97)\end{array}$ \\
\hline polity & $\begin{array}{r}0.002 \\
(0.21)\end{array}$ & $\begin{array}{r}0.003 \\
(0.29)\end{array}$ & $\begin{array}{r}0.017 \\
(1.08)\end{array}$ & $\begin{array}{c}0.0375 \\
(2.01)^{* *}\end{array}$ & $\begin{array}{r}0.035 \\
(1.56)\end{array}$ & $\begin{array}{c}0.036 \\
(1.79)^{\star}\end{array}$ \\
\hline peaceyrs & $\begin{array}{l}-0.021 \\
(4.02)^{\star \star *}\end{array}$ & $\begin{array}{l}-0.02 \\
(3.91)^{\star * *}\end{array}$ & $\begin{array}{l}-0.018 \\
(2.86)^{\star * *}\end{array}$ & $\begin{array}{c}-0.011 \\
(-1.55)\end{array}$ & $\begin{array}{c}-0.008 \\
(-0.79)\end{array}$ & $\begin{array}{r}-0.011 \\
(1.53)\end{array}$ \\
\hline frafcol & $\begin{array}{c}-0.663 \\
(1.91)^{\star}\end{array}$ & $\begin{array}{c}-0.677 \\
(1.95)^{\star}\end{array}$ & $\begin{array}{c}-0.308 \\
(0.77)\end{array}$ & $\begin{array}{r}-0.63 \\
(1.60)\end{array}$ & $\begin{array}{l}-0.493 \\
(-0.89)\end{array}$ & $\begin{array}{c}-0.622 \\
(1.55)\end{array}$ \\
\hline youngmenpop & $\begin{array}{c}1.632 \\
(0.36)\end{array}$ & $\begin{array}{c}1.631 \\
(0.36)\end{array}$ & $\begin{array}{c}8.041 \\
(1.13)\end{array}$ & $\begin{array}{c}8.886 \\
(1.09)\end{array}$ & $\begin{array}{c}5.719 \\
(0.59)\end{array}$ & $\begin{array}{c}9.944 \\
(1.19)\end{array}$ \\
\hline mountain & $\begin{array}{r}0.005 \\
(1.37)\end{array}$ & $\begin{array}{r}0.005 \\
(1.35)\end{array}$ & $\begin{array}{c}0.007 \\
(1.65)^{\star}\end{array}$ & $\begin{array}{r}0.003 \\
(0.69)\end{array}$ & $\begin{array}{r}0.007 \\
(1.01)\end{array}$ & $\begin{array}{c}0.004 \\
(0.74)\end{array}$ \\
\hline $\begin{array}{l}\text { Res abund. var. } \\
\text { Observations }\end{array}$ & 865 & 865 & 696 & $\begin{array}{l}\text { Innatcap } \\
688\end{array}$ & $\begin{array}{l}\text { Insubsoil } \\
505\end{array}$ & $\begin{array}{l}\text { lnland } \\
676\end{array}$ \\
\hline Pseudo R2 & 0.21 & 0.21 & 0.21 & & & \\
\hline Log likelihood & -176.1 & -176.1 & -116.2 & & & \\
\hline Correctly classified & $\begin{array}{l}93.06 \% \\
(4 / 62,2)\end{array}$ & $\begin{array}{l}93.18 \% \\
(4 / 62,1)\end{array}$ & $\begin{array}{l}94.54 \% \\
(1 / 38,1)\end{array}$ & $\begin{array}{r}94.04 \% \\
(4 / 38,7)\end{array}$ & $\begin{array}{r}94.04 \% \\
(2 / 23,5)\end{array}$ & $\begin{array}{r}93.93 \% \\
(3 / 37,7)\end{array}$ \\
\hline Wald exogeneity $\mathrm{p}$ & & & & $\begin{array}{l}0.0200 \\
0.0089\end{array}$ & $\begin{array}{l}0.0655 \\
0.0524\end{array}$ & $\begin{array}{l}0.0519 \\
0.0206\end{array}$ \\
\hline
\end{tabular}

Notes: Dependent variable is warstart. $2^{\text {nd }}$ stage results shown for IV-probit estimations in columns (4)-(6). Correctly classified in percent; amount wars predicted correctly out of total and amount falsely predicted wars given in parentheses below. p-values given for Wald test of exogeneity and joint endogeneity test (Wu-Hausman test in linear regression). Absolute value of z-statistics in parentheses. ${ }^{*},{ }^{* *},{ }^{* *}$ statistically significant at $10 \%, 5 \%$, and $1 \%$ levels, respectively. All regressions include an intercept (not shown).

reason to suspect that resource dependence and income may be endogenous. For this reason we proceed by simultaneously instrumenting for these variables in a series of follow-up regressions.

In columns (4)-(6) we apply a pooled two-step ivprobit model, where the two endogenous variables are estimated in the first stage by a simple linear regression as 
Table 2b First stage results from ivprobit estimations

\begin{tabular}{|c|c|c|c|c|c|c|}
\hline Panel B & $\begin{array}{c}(1) \\
\text { lnsxp from } \\
\text { spec. }(4)\end{array}$ & $\begin{array}{c}(2) \\
\text { lnsxp from } \\
\text { spec. }(5)\end{array}$ & $\begin{array}{c}(3) \\
\text { lnsxp from } \\
\text { spec. }(6)\end{array}$ & $\begin{array}{c}(4) \\
\text { lngdp from } \\
\text { spec. }(4)\end{array}$ & $\begin{array}{c}(5) \\
\text { lngdp from } \\
\text { spec. (5) }\end{array}$ & $\begin{array}{c}(6) \\
\text { lngdp from } \\
\text { spec. }(6)\end{array}$ \\
\hline lnnatcap & $\begin{array}{c}0.351 \\
(12.43)^{* * *}\end{array}$ & & & $\begin{array}{c}0.423 \\
(16.35)^{* * *}\end{array}$ & & \\
\hline lnsubsoil & & $\begin{array}{c}0.156 \\
(11.72)^{* * *}\end{array}$ & & & $\begin{array}{c}0.176 \\
(13.86)^{\star * *}\end{array}$ & \\
\hline lnland & & & $\begin{array}{l}0.25 \\
(8.03)^{\star * *}\end{array}$ & & & $\begin{array}{c}0.34 \\
(11.80)^{\star * *}\end{array}$ \\
\hline openness & $\begin{array}{c}0.009 \\
(8.23)^{\star * *}\end{array}$ & $\begin{array}{l}0.009 \\
(7.27)^{\star * *}\end{array}$ & $\begin{array}{l}0.008 \\
(6.88)^{\star * *}\end{array}$ & $\begin{array}{l}0.005 \\
(5.15)^{\star * *}\end{array}$ & $\begin{array}{c}0.001 \\
(0.99)\end{array}$ & $\begin{array}{l}0.004 \\
(4.26)^{* * *}\end{array}$ \\
\hline presidential & $\begin{array}{c}0.186 \\
(2.45)^{\star *}\end{array}$ & $\begin{array}{l}0.274 \\
(3.41)^{\star * *}\end{array}$ & $\begin{array}{l}0.162 \\
(2.06)^{\star \star}\end{array}$ & $\begin{array}{l}-0.16 \\
(2.31)^{* *}\end{array}$ & $\begin{array}{r}0.097 \\
(1.27)\end{array}$ & $\begin{array}{l}-0.202 \\
(2.78)^{\star * \star}\end{array}$ \\
\hline latitude & $\begin{array}{c}0.587 \\
(1.76)^{\star}\end{array}$ & $\begin{array}{l}1.583 \\
(4.78)^{\star \star \star}\end{array}$ & $\begin{array}{c}0.602 \\
(1.74)^{\star}\end{array}$ & $\begin{array}{l}0.782 \\
(2.56)^{\star \star *}\end{array}$ & $\begin{array}{l}1.806 \\
(5.72)^{\star * \star}\end{array}$ & $\begin{array}{c}0.702 \\
(2.19)^{\star *}\end{array}$ \\
\hline distcr & $\begin{array}{c}-0.00002 \\
(0.26)\end{array}$ & $\begin{array}{c}-0.0001 \\
(1.31)\end{array}$ & $\begin{array}{c}-0.0001 \\
(0.71)\end{array}$ & $\begin{array}{l}-0.0005 \\
(5.73)^{\star * \star}\end{array}$ & $\begin{array}{l}-0.0008 \\
(7.50)^{\star * *}\end{array}$ & $\begin{array}{c}-0.0005 \\
(5.80)^{* * *}\end{array}$ \\
\hline tropics & $\begin{array}{c}0.905 \\
(7.17)^{\star * \star}\end{array}$ & $\begin{array}{l}1.064 \\
(8.12)^{\star * \star}\end{array}$ & $\begin{array}{l}0.884 \\
(6.79)^{\star * *}\end{array}$ & $\begin{array}{l}-0.416 \\
(3.61)^{\star \star \star}\end{array}$ & $\begin{array}{l}-0.34 \\
(2.72)^{\star \star \star}\end{array}$ & $\begin{array}{l}-0.445 \\
(3.70)^{\star * \star}\end{array}$ \\
\hline peace years & $\begin{array}{l}-0.005 \\
(2.68)^{* * *}\end{array}$ & $\begin{array}{l}-0.004 \\
(2.18)^{\star \star}\end{array}$ & $\begin{array}{l}-0.005 \\
(2.82)^{\star \star \star}\end{array}$ & $\begin{array}{l}0.007 \\
(4.63)^{\star * \star}\end{array}$ & $\begin{array}{l}0.013 \\
(7.00)^{\star * \star}\end{array}$ & $\begin{array}{l}0.007 \\
(4.37)^{\star * \star}\end{array}$ \\
\hline Adj R2 & 0.57 & 0.70 & 0.54 & 0.75 & 0.75 & 0.73 \\
\hline
\end{tabular}

Notes: $1^{\text {st }}$ stage results for all exogenous instruments from two-step IV-probit in Panel A, plus coefficient for years of peace. Over-identification tests from linear regressions for specifications (4), (5), and (6) are respectively: (Sargan $\mathrm{N}^{*} \mathrm{R}$-sq 0.1516, Basmann 0.1564), (0.3894, 0.4013), (0.1092, 0.1128). F-statistics for tests on excluded instruments from linear regressions for lnsxp and lngdp in specifications (4), (5), and (6) are respectively: $(49.62,93.64),(51.82,63.36),(31.30,65.77)$. Absolute value of t-statistics in parentheses. ${ }^{*}, * * * *$ statistically significant at $10 \%, 5 \%$, and $1 \%$ levels, respectively. All regressions include an intercept (not shown).

in eq. (1), while the second stage uses a probit approach to determine the probability of the onset of war, following eq. $\left(2^{\prime}\right)$. The available exogenous instruments for dependence and income include openness, presidential, latitude, distcr, and tropics. We now also include resource abundance as an exogenous instrument, since the second-stage results and test statistics clearly indicate that abundance has no significant direct effects on the onset of conflict after instrumenting for dependence and income (implying that the effects of abundance are indirect- -see Brunnschweiler and Bulte, 2008, for additional discussion and motivation). ${ }^{11}$ Equation (2) is therefore not the most appropriate approach.

\footnotetext{
${ }^{11}$ If included in the second-stage specification (i.e. not as exogenous instruments in the first stage only), the total natural capital and subsoil variables both enter with a positive sign with p-values of 0.981 and 0.473 , respectively. Land has a negative sign and a p-value of 0.826 . Identification tests for all resource abundance measures show that they are proper exogenous instruments.
} 
First-stage regression results for our six exogenous instruments, matching the regressions in columns (4)-(6) in Panel A, are provided in Panel B of Table 2. Results for resource dependence are reported in columns (1)-(3), and for income in columns (4)-(6). The three ivprobit specifications shown correspond to three different resource abundance variables in the first stage. In specification (4) (columns (1) and (4) of Panel B) we use the aggregate resource abundance variable. In contrast, specification (5) (columns (2) and (5)) is based on subsoil resources only (fuel and non-fuel mineral resources), and specification (6) (columns (3) and (6)) is based on land.

The first-stage results are consistent with intuition and show that our instruments are strong. ${ }^{12}$ Resource dependence is a positive function of all three measures of resource abundance, openness to trade, a presidential dummy, and tropical area. Income is a positive function of resource abundance, openness, and latitude, and negatively affected by presidential systems, distance to navigable rivers and the coast, and tropical land area. While the positive correlation between resource abundance and income appears counterintuitive in light of the resource curse literature relating resources to slow growth, it is consistent with results reported Brunnschweiler and Bulte (2008), and it is arguably in line with a positive income effect due to resource wealth. This positive income effect could be due for example to the sale of resources or-indirectly - to an improved capacity to borrow money (i.e. resources as collateral), enabling governments to invest or provide certain public goods that raise income. However, we are reluctant to speculate on the exact transmission channels without a more detailed analysis, which goes beyond the scope of this paper.

Returning to Panel A, the test statistics at the bottom-the Wald exogeneity test from the ivprobit estimation and the joint endogeneity test from linear estimation-provide clear support for the idea that income and resource dependence are jointly endogenous, and that instrumenting for these variables is necessary to obtain unbiased estimates of the causal relationships running from dependence and income to the onset of conflict. The test statistics also confirm that the instruments are appropriate: over-identification tests (Basmann and Sargan $N^{\star} \mathrm{R}$-square tests) and the tests on the excluded instruments, all performed in linear regression, ${ }^{13}$ show that we have strong and properly exogenous instruments (see the

\footnotetext{
${ }^{12}$ The over-identification test results for specification (6) are borderline. However, upon removing the presidentialism variable, the statistic jumps up to 0.5 without qualitatively affecting any of the other coefficients or standard errors. For consistency we have chosen to present the results using all six exogenous instruments in every specification. Note that in all estimations, results do not change qualitatively when we remove either the resource abundance or trade openness instrument, or both.

${ }^{13}$ As one referee pointed out, this means that the test results reported in the paper should be interpreted with some caution, as they are not adjusted for the second-stage probit estimation: the linear treatment slightly changes the results, but they are generally close enough to be able to have confidence in the test statistics.
} 
notes to Table 2 for details). We also note that the ivprobit procedure improves the overall predictive strength of the model. ${ }^{14}$

The most important results are threefold. First, the peace variable is no longer significant. Instead, first-stage results presented in Panel B show that peace is strongly correlated with both lower resource dependence and higher per capita incomes. In preliminary dynamic panel data estimations (results available upon request), this reverse causality appears confirmed: peace diminishes resource dependence, and resource dependence does not make conflict more likely. This issue deserves a more in-depth analysis in future research. Second, higher incomes again attenuate the risk of conflict. Indeed, its coefficient has nearly tripled and is consistently highly significant. Third, there is no evidence of a negative causal relation from dependence to conflict. After we instrument for dependence, the effect vanishes, which suggests the correlation between these variables was in part driven by the impact of conflict on the composition of exports and income-shifting in favour of primary commodities. Columns (4)-(6) indicate that this is true for our aggregate abundance measure, for subsoil resources, and also for land. ${ }^{15}$

This brings us to our main result. Resource-rich countries are not generally 'cursed' in the sense that they run a greater risk of being torn apart by civil wars. Indeed, the opposite seems true: resource wealth has a positive and significant effect on income, and this in turn reduces the risk of war. Our results support the alternative hypothesis that resource scarcity may be a trigger of conflict. While some analysts have argued that scarcity might be especially relevant in the context of land-based resources (Andre and Platteau, 1998), our findings suggests that the mechanism may be more general. As far as the magnitude of this effect is concerned, we find that increasing resource abundance by one standard deviation reduces the risk of war from $7.1 \%$ to $6.9 \%$, or a $3 \%$ reduction in risk (evaluating variables at the sample mean).

\subsection{Robustness analysis}

Are these results robust to alternative model specifications? In Table 3 we provide the second-stage results of a series of representative examples (first-stage results for income and dependence are omitted to save space, but are similar to those shown in Table 2, Panel B). While the significance of specific control variables varies across specifications (e.g., fractionalization, polity, duration of peace and the French colony dummy), our main results are robust. Similarly (but not

\footnotetext{
${ }^{14}$ Note that the use of the efficient two-step ivprobit procedure precludes the possibility of calculating post-estimation statistics such as marginal effects and goodness-of-fit measures. Where possible, these were estimated with maximum-likelihood ivprobits; where no goodness-of-fit measures are reported, no convergence occurred.

${ }^{15}$ We have also experimented with using an alternative resource dependence variable. Specifically, we have used $\log$ (mineral exports) capturing fuels, ores and metals, and find very similar results: (instrumented) dependence is not significant, and there is a positive indirect effect of abundance via income.
} 
Table 3 Specification tests

\begin{tabular}{|c|c|c|c|c|c|c|}
\hline & (1) & (2) & (3) & (4) & (5) & (6) \\
\hline $\operatorname{lnsxp}$ & $\begin{array}{c}-0.212 \\
(0.85)\end{array}$ & $\begin{array}{c}-0.065 \\
(0.27)\end{array}$ & $\begin{array}{c}0.097 \\
(0.33)\end{array}$ & $\begin{array}{r}-0.251 \\
(0.82)\end{array}$ & $\begin{array}{c}0.121 \\
(0.42)\end{array}$ & $\begin{array}{c}0.081 \\
(0.26)\end{array}$ \\
\hline lngdp & $\begin{array}{l}-0.840 \\
(3.71)^{\star \star \star}\end{array}$ & $\begin{array}{l}-0.774 \\
(3.19)^{\star \star \star}\end{array}$ & $\begin{array}{l}-1.338 \\
(3.98)^{\star * *}\end{array}$ & $\begin{array}{l}-0.802 \\
(3.61)^{\star * *}\end{array}$ & $\begin{array}{l}-0.702 \\
(3.04)^{\star \star \star}\end{array}$ & $\begin{array}{l}-0.716 \\
(2.94)^{\star * *}\end{array}$ \\
\hline growth & $\begin{array}{c}-0.073 \\
(1.76)^{\star}\end{array}$ & $\begin{array}{c}-0.079 \\
(1.86)^{\star}\end{array}$ & $\begin{array}{c}-0.082 \\
(1.95)^{\star}\end{array}$ & $\begin{array}{l}-0.055 \\
(2.13)^{\star *}\end{array}$ & $\begin{array}{l}-0.102 \\
(3.36)^{\star * *}\end{array}$ & $\begin{array}{l}-0.098 \\
(3.20)^{\star * *}\end{array}$ \\
\hline $\operatorname{lnpop}$ & $\begin{array}{r}0.017 \\
(0.15)\end{array}$ & $\begin{array}{c}0.113 \\
(1.02)\end{array}$ & $\begin{array}{c}0.068 \\
(0.60)\end{array}$ & $\begin{array}{c}0.039 \\
(0.38)\end{array}$ & $\begin{array}{c}0.189 \\
(1.92)^{\star}\end{array}$ & $\begin{array}{c}0.173 \\
(1.66)^{\star}\end{array}$ \\
\hline socialfrac & & $\begin{array}{c}-0.0001 \\
(1.14)\end{array}$ & $\begin{array}{c}-0.0001 \\
(0.63)\end{array}$ & $\begin{array}{c}-0.0001 \\
(1.45)\end{array}$ & $\begin{array}{c}-0.0001 \\
(1.66)^{\star}\end{array}$ & $\begin{array}{c}-0.0001 \\
(1.62)\end{array}$ \\
\hline polity & $\begin{array}{c}0.036 \\
(1.82)^{\star}\end{array}$ & $\begin{array}{l}0.044 \\
(2.22)^{\star *}\end{array}$ & $\begin{array}{c}0.053 \\
(2.60)^{\star * *}\end{array}$ & $\begin{array}{r}0.017 \\
(1.10)\end{array}$ & $\begin{array}{r}0.025 \\
(1.51)\end{array}$ & $\begin{array}{r}0.023 \\
(1.38)\end{array}$ \\
\hline peaceyrs & $\begin{array}{r}-0.002 \\
(0.24)\end{array}$ & $\begin{array}{l}-0.016 \\
(2.05)^{\star *}\end{array}$ & $\begin{array}{r}0.001 \\
(0.06)\end{array}$ & $\begin{array}{l}-0.014 \\
(2.31)^{\star *}\end{array}$ & $\begin{array}{l}-0.012 \\
(1.99)^{\star *}\end{array}$ & $\begin{array}{l}-0.012 \\
(2.02)^{\star *}\end{array}$ \\
\hline frafcol & $\begin{array}{c}-0.741 \\
(1.68)^{\star}\end{array}$ & $\begin{array}{c}-0.666 \\
(1.68)^{\star}\end{array}$ & $\begin{array}{c}-0.346 \\
(0.82)\end{array}$ & $\begin{array}{l}-0.828 \\
(2.25)^{\star *}\end{array}$ & $\begin{array}{l}-0.817 \\
(2.15)^{\star *}\end{array}$ & $\begin{array}{l}-0.839 \\
(2.21)^{* *}\end{array}$ \\
\hline youngmenpop & $\begin{array}{l}10.46 \\
(1.18)\end{array}$ & $\begin{array}{c}6.143 \\
(0.68)\end{array}$ & $\begin{array}{c}4.177 \\
(0.48)\end{array}$ & $\begin{array}{r}7.031 \\
(1.25)\end{array}$ & $\begin{array}{c}0.581 \\
(0.11)\end{array}$ & $\begin{array}{r}1.230 \\
(0.23)\end{array}$ \\
\hline mountain & $\begin{array}{r}0.005 \\
(1.05)\end{array}$ & $\begin{array}{c}0.003 \\
(0.69)\end{array}$ & $\begin{array}{c}0.004 \\
(0.68)\end{array}$ & $\begin{array}{r}-0.002 \\
(0.50)\end{array}$ & $\begin{array}{c}0.003 \\
(0.61)\end{array}$ & $\begin{array}{c}0.002 \\
(0.42)\end{array}$ \\
\hline ethnicpol & $\begin{array}{l}1.645 \\
(2.65)^{* * *}\end{array}$ & & & & & \\
\hline instability & $\begin{array}{r}0.242 \\
(1.06)\end{array}$ & & & & & \\
\hline new state & $\begin{array}{c}0.337 \\
(0.44)\end{array}$ & & & & & \\
\hline non contiguous & $\begin{array}{r}0.556 \\
(1.57)\end{array}$ & & & & & \\
\hline inequality & $\begin{array}{c}-0.014 \\
(1.19)\end{array}$ & & & & & \\
\hline dum70s & & $\begin{array}{c}0.772 \\
(2.44)^{\star *}\end{array}$ & & & & \\
\hline dum80s & & $\begin{array}{c}0.583 \\
(1.65)^{\star}\end{array}$ & & & & \\
\hline dum90s & & $\begin{array}{c}0.634 \\
(1.74)^{\star}\end{array}$ & & & & \\
\hline dum00s & & $\begin{array}{c}0.329 \\
(0.77)\end{array}$ & & & & \\
\hline ssa & & & $\begin{array}{l}-1.579 \\
(2.70)^{\star \star *}\end{array}$ & & & \\
\hline latam & & & $\begin{array}{c}-0.544 \\
(1.51)\end{array}$ & & & \\
\hline Res. abund. var. & lnnatcap & lnnatcap & lnnatcap & minerals $\mathrm{pc}$ & oil prod pc & oil res pc \\
\hline Observations & 671 & 688 & 688 & 814 & 808 & 810 \\
\hline Correctly classified & & $\begin{array}{r}94.33 \% \\
(5 / 38,6)\end{array}$ & & $\begin{array}{c}91.52 \% \\
(8 / 61,16)\end{array}$ & $\begin{array}{r}92.45 \% \\
(5 / 58,8)\end{array}$ & $\begin{array}{r}92.35 \% \\
(5 / 59,8)\end{array}$ \\
\hline Wald exogeneity p & 0.0097 & 0.0442 & 0.001 & 0.0314 & 0.109 & 0.108 \\
\hline Joint endogeneity $p$ & 0.0009 & 0.0389 & 0.0001 & 0.0573 & 0.116 & 0.0964 \\
\hline
\end{tabular}


Table 3 Continued

(1)

\begin{tabular}{lllllll}
\hline Instrument overid p & 0.9105 & 0.1149 & 0.244 & 0.0556 & 0.0136 & 0.0243 \\
Excl. instr. F lnsxp & 42.84 & 49.42 & 42.51 & 25.82 & 31.88 & 24.81 \\
Excl. instr. F lngdp & 83.64 & 93.01 & 49.62 & 52.03 & 65.18 & 50.03 \\
\hline
\end{tabular}

Notes: All estimations IV-probit; only $2^{\text {nd }}$ stage results shown, with warstart as dependent variable. Exogenous instruments for lnsxp and lngdp in $1^{\text {st }}$ stage are openness, presidential, latitude, tropics, distcr, and a natural resource abundance measure. The natural resource abundance variable in columns (1)-(3) is taken from the World Bank; per capita values of fuel and non-fuel minerals in 1970 in column (4) based on data by Norman (2009); per capita oil production and reserves data in columns (5) and (6), respectively, are from Humphreys (2005). Correctly classified in percent; amount wars predicted correctly out of total and amount falsely predicted wars given in parentheses. Joint endogeneity test (Wu-Hausman), instrument over-identification test (Sargan $\mathrm{N}^{*} \mathrm{R}-\mathrm{sq}$ ), and tests on excluded instruments (F-statistics) performed in linear regression. Absolute value of $\mathrm{z}$-statistics in parentheses. ${ }^{*}, * *, * *$ statistically significant at $10 \%, 5 \%$, and $1 \%$ levels, respectively. All regressions include an intercept (not shown).

shown - details available on request) we found the same set of results when switching to a linear pooled 3SLS approach (predicting income, dependence, and the onset of civil war in three simultaneous equations).

In column (1) we explore the consequences of introducing additional controls commonly used in conflict regressions (e.g., Fearon and Laitin, 2003; Ross, 2006), as well as substituting the social fractionalization variable for a measure of ethnic polarization developed by Reynal-Querol (2002). Social fractionalization has been a popular measure in the conflict literature, but polarization may better capture ethnic divisions. Ethnic polarization consistently enters positively and significantly, showing that polarization between a limited number of ethnic groups is more likely to lead to conflict than a highly fractionalized society with many small groups. However, the introduction of this variable does not alter our main results: resource dependence is still not significantly different from zero, and abundance lowers the risk of the onset of conflict via an income effect.

Our main results also prove robust to including measures of political instability, a dummy for newly independent states or for countries with non-contiguous territories, and income inequality (column (1)), or period or decade dummies (the latter is shown in column (2)). In column (3), we introduce regional dummies for Latin America (latam) and Sub-Saharan Africa (ssa). Again, the main coefficients of interest are unaffected. Interestingly, and in contrast to our expectations, the African dummy enters significantly and with a negative sign.

In columns (4)-(6) we use alternative abundance variables, and demonstrate that our results are no artefact of our abundance measure. The alternative datasets have wider coverage than the World Bank dataset, increasing the number of observations as well as the included conflict episodes.

In column (4) we use a new mineral reserves dataset constructed by Norman (2009). All our previous results carry through. First-stage results (not shown) 
again indicate a positive and significant relation between abundance and income, and the second-stage results confirm that income negatively affects conflict risk-the same indirect channel as identified and discussed above. Moreover, using this new abundance variable to instrument for resource dependence again shows that $\ln \operatorname{sxp}$ is no longer significant.

In columns (5) and (6) we use an even narrower resource abundance variable, and focus on oil only. As mentioned above, various authors implicate oil as a driver of the onset of war, and especially in the post Cold War era there are several high-profile case studies of conflict where oil appears to have played a role. To analyse this we take, respectively, per capita oil production and oil reserves data from Humphreys (2005). While we are not confident that the production data are fully exogenous (the reserves data are more consistent with the other abundance variables used in this paper), it is comforting to observe that our main first and second stage results are confirmed. These results provide no support for the idea of a special 'curse of oil', suggesting that conceptual distinctions between point and diffuse resources (e.g., Isham et al., 2005; Bulte et al., 2005) may not be that relevant across-the-board in the context of predicting civil wars.

Note that although the F-statistics for the excluded instruments remain strong, the over-identification tests in columns (4)-(6) of Table 3 indicate that not all instruments are valid. The problematic instruments turn out to be the measure of land area in the tropics in all three specifications, and additionally the presidential dummy in specifications (5) and (6). Dropping these instruments improves the test statistics, leaving us with a set of strong exogenous instruments without qualitatively affecting our main results.

Results from further robustness tests are reported in Table 4. Column (2) reports results from a random-effects panel regression while instrumenting for income and resource dependence, using the same data as before. ${ }^{16}$ In contrast to earlier, pooled ivprobit analyses, we have now estimated a linear equation. Regardless, we find the main results are robust with respect to the nature of the estimation method.

In column (3) we adjust our approach of tackling ongoing conflict, coding it as 0 instead of missing, and adding a dummy variable for conflict in the previous period instead of peace years to avoid confusing war onset and duration. While including a dummy for ongoing conflict does not affect any of our main results from the first and second stages, it does compromise significance levels of some of our control

\footnotetext{
${ }^{16}$ Note that a random effects model assumes that the country fixed effects are uncorrelated with the error term and other explanatory variables. This strong assumption is unlikely to be fully satisfied, and the random effects results should be interpreted with proper caution. However, while a fixed effects model would arguably be preferable, we prefer not to use such a specification because several of our explanatory variables and exogenous instruments display little or no variation over time. A fixed effects model renders some of our key results insignificant, although the signs remain consistent (results available from the authors on request).
} 
Table 4 Robustness tests

\begin{tabular}{|c|c|c|c|c|c|}
\hline & $\begin{array}{l}(1) \\
\text { COW } \\
\text { relogit }\end{array}$ & $\begin{array}{c}(2) \\
\text { COW } \\
\text { xtivreg }\end{array}$ & $\begin{array}{c}(3) \\
\text { COW with } \\
\text { ongoing } \\
\text { conflict } \\
\text { ivprobit }\end{array}$ & ivprobit & $\begin{array}{c}(5) \\
\text { ACD with } \\
\text { ongoing } \\
\text { conflict } \\
\text { ivprobit }\end{array}$ \\
\hline $\operatorname{lnsxp}$ & $\begin{array}{r}0.217 \\
(0.66)\end{array}$ & $\begin{array}{r}-0.002 \\
(0.09)\end{array}$ & $\begin{array}{r}-0.065 \\
(0.28)\end{array}$ & $\begin{array}{l}0.627 \\
(2.60)^{\star * *}\end{array}$ & $\begin{array}{c}0.559 \\
(2.62)^{\star * *}\end{array}$ \\
\hline lnnatcap & $\begin{array}{c}-0.544 \\
(1.86)^{\star}\end{array}$ & & & & \\
\hline $\operatorname{lngdp}$ & $\begin{array}{c}-0.484 \\
(1.79)^{\star}\end{array}$ & $\begin{array}{l}-0.070 \\
(4.10)^{* * *}\end{array}$ & $\begin{array}{l}-0.804 \\
(3.57)^{\star * *}\end{array}$ & $\begin{array}{l}-0.748 \\
(3.66)^{* * *}\end{array}$ & $\begin{array}{l}-0.618 \\
(3.42)^{\star * \star}\end{array}$ \\
\hline growth & $\begin{array}{l}-0.193 \\
(2.34)^{\star *}\end{array}$ & $\begin{array}{l}-0.009 \\
(2.51)^{\star *}\end{array}$ & $\begin{array}{c}-0.064 \\
(1.69)^{\star}\end{array}$ & $\begin{array}{c}0.002 \\
(0.06)\end{array}$ & $\begin{array}{r}0.001 \\
(0.03)\end{array}$ \\
\hline $\operatorname{lnpop}$ & $\begin{array}{c}0.240 \\
(1.33)\end{array}$ & $\begin{array}{r}0.012 \\
(1.27)\end{array}$ & $\begin{array}{c}0.114 \\
(1.10)\end{array}$ & $\begin{array}{c}0.373 \\
(3.62)^{* * *}\end{array}$ & $\begin{array}{l}0.297 \\
(3.34)^{\star * *}\end{array}$ \\
\hline socialfrac & $\begin{array}{c}-0.0001 \\
(0.69)\end{array}$ & $\begin{array}{c}-0.00001 \\
(1.54)\end{array}$ & $\begin{array}{c}-0.0001 \\
(1.28)\end{array}$ & $\begin{array}{c}-0.0001 \\
(2.15)^{\star \star}\end{array}$ & $\begin{array}{c}-0.0001 \\
(2.33)^{\star *}\end{array}$ \\
\hline polity & $\begin{array}{c}0.034 \\
(1.06)\end{array}$ & $\begin{array}{c}0.004 \\
(2.20)^{\star \star}\end{array}$ & $\begin{array}{c}0.032 \\
(1.72)^{\star}\end{array}$ & $\begin{array}{c}0.035 \\
(2.10)^{* *}\end{array}$ & $\begin{array}{r}0.023 \\
(1.46)\end{array}$ \\
\hline peace years & $\begin{array}{l}-0.031 \\
(2.74)^{* * *}\end{array}$ & $\begin{array}{l}-0.001 \\
(2.28)^{\star *}\end{array}$ & & $\begin{array}{r}0.001 \\
(0.09)\end{array}$ & \\
\hline previous conflict & & & $\begin{array}{c}0.041 \\
(0.16)\end{array}$ & & $\begin{array}{c}-0.164 \\
(0.98)\end{array}$ \\
\hline frafcol & $\begin{array}{r}-0.249 \\
(0.29)\end{array}$ & $\begin{array}{l}-0.063 \\
(1.97)^{\star *}\end{array}$ & $\begin{array}{c}-0.708 \\
(1.87)^{\star}\end{array}$ & $\begin{array}{r}-0.131 \\
(0.52)\end{array}$ & $\begin{array}{r}-0.112 \\
(0.48)\end{array}$ \\
\hline youngmenpop & $\begin{array}{l}16.79 \\
(1.49)\end{array}$ & $\begin{array}{c}0.470 \\
(0.79)\end{array}$ & $\begin{array}{c}6.944 \\
(0.87)\end{array}$ & $\begin{array}{r}-1.631 \\
(0.30)\end{array}$ & $\begin{array}{r}-5.210 \\
(1.06)\end{array}$ \\
\hline mountain & $\begin{array}{c}0.015 \\
(1.73)^{*}\end{array}$ & $\begin{array}{c}0.001 \\
(1.77)^{\star}\end{array}$ & $\begin{array}{c}0.003 \\
(0.65)\end{array}$ & $\begin{array}{c}0.003 \\
(0.75)\end{array}$ & $\begin{array}{r}0.002 \\
(0.47)\end{array}$ \\
\hline Observations & 696 & 688 & 728 & 649 & 736 \\
\hline Wald exogeneity $\mathrm{p}$ & & & 0.0184 & 0.0023 & 0.0057 \\
\hline Joint endogeneity $\mathrm{p}$ & & & 0.0348 & 0.0138 & 0.0212 \\
\hline Instrument overid $\mathrm{p}$ & & & 0.1161 & 0.5573 & 0.4091 \\
\hline Excl. instr. F lnsxp & & & 51.61 & 63.18 & 74.74 \\
\hline Excl. instr. F lnsxp & & & 98.03 & 139.87 & 155.37 \\
\hline
\end{tabular}

Notes: Dependent variable is warstart according to two different datasets: Correlates of War (COW) by Gleditsch (2004) and Armed Conflict Database (ACD) by Gleditsch et al. (2002). Column (1) shows a basic regression performed with rare events logit, corresponding to Table 2, column (3). Column (2) shows core specification (corresponding to Table 2, column (4)) in linear random effects panel IV regression. Columns (3) and (5) code ongoing conflicts as 0 instead of missing and include a dummy variable for conflict in the previous period. Only $2^{\text {nd }}$ stage results shown. Exogenous instruments for lnsxp and lngdp in $1^{\text {st }}$ stage are openness, latitude, and total natural resource wealth (lnnatcap) in columns (4)-(5), and additionally presidential, tropics, and distcr in columns (2)-(3). Joint endogeneity test (Wu-Hausman), instrument over-identification test (Sargan $\mathrm{N}^{\star} \mathrm{R}$-sq), and tests on excluded instruments (F-statistics) performed in linear regression. Absolute value of $\mathrm{z}$-statistics in parentheses. ${ }^{*},{ }^{* *},{ }^{* *}$ statistically significant at $10 \%, 5 \%$, and $1 \%$ levels, respectively. All regressions include an intercept (not shown). 
variables (population size, fractionalization, mountainous territory), although there is little change in the magnitude of the coefficients. In the first stage, violent conflict in the previous period still increases resource dependence (the coefficient of the dummy variable is significant at the $10 \%$ level), while it does not significantly affect income levels.

Columns (4) and (5) represent a radical departure from our earlier regressions, as we now switch to another dependent variable-the conflict dummy from the Armed Conflict Database (ACD). The obvious difference with our earlier 'onset of war' variable, taken from the Correlates of War (COW) dataset, is that the ACD variable captures more violent incidents. Specifically, the ACD dataset takes 25 battle-deaths per year as the threshold value above which an incident is counted, and the COW variable only includes violence with an annual death toll exceeding 1000. As a result of the lower threshold, the number of 'war' observations in the sample increases to around 90. Arguably, violent incidents with a number of casualties close to the 25 threshold level do not represent war as commonly understood, but it is interesting to see if small-scale violence responds to the same triggers as civil war.

Columns (4) and (5) suggest it does not. In column (4) we report results using the two-step ivprobit routine as above with ongoing conflicts coded as missing, and in column (5) we again code it as 0 and introduce a dummy variable to capture previous conflict. We find the results using the ACD data are different from the ones for the COW dataset. First-stage results still suggest that previous episodes of conflict significantly increase resource dependence. Moreover, while it is still the case that resource abundance has an important indirect and attenuating effect on the onset of violence via income, we now also find that resource dependence enters significant and positive. ${ }^{17}$ With other words, resources-or possibly the distribution of resource rents-do not seem a reason for full-blown war, where issues related to grievance (e.g., economic underdevelopment) appear to be more important; but they may trigger smaller-scale conflicts.

Since resource abundance increases both income and dependence in the first stage, and since income and dependence have opposite effects in the second stage, the net effect of abundance on small scale violence is ambiguous. Combining results from the first and second stages, we can assess the net effect of resources on violence. Specifically, a one-standard deviation increase in resource abundance decreases the risk of all levels of conflict via higher incomes by around $0.46 \%$, and simultaneously increases the risk via increased resource dependence by circa $0.38 \%$. The net effect of resource abundance, therefore, continues to be a reduction

\footnotetext{
${ }^{17}$ We have repeated this analysis using subsoil and land-based resource abundance variables, and the qualitative results are identical to the ones for the aggregate abundance variable. Note that the presidential dummy variable, tropical location and distance to the coast or navigable river proved weak instruments in the specifications using the ACD dataset and were therefore dropped, leaving three strong exogenous instruments.
} 
in the probability of conflict, although the limited magnitude in fact suggests that resources are not a major determinant of conflict in any event.

\section{Discussion and conclusions}

According to both the economics and political science literature, natural resources tend to magnify the risk of civil war. This resource-war link is often viewed as one of the dimensions of the paradoxical resource curse perspective-the view that more of a good thing may be bad for development.

In this paper we qualify this interpretation, and indeed turn received wisdom upside down. We find evidence of a link between resource wealth and the onset of conflict, but demonstrate that it runs opposite to the usual perspective. Resource wealth, via an income effect, lowers the probability of conflict, and especially of the onset of a major conflict. Moreover, we find no evidence of an across-the-board link running from resource dependence to civil war. Instead, the opposite chain of causation appears true-conflict-torn societies become dependent on natural resources, which arguably is hardly a paradox. Economic success and peace are signalled by economic diversification and low dependence on natural resources (even if such resources are physically abundant). Our findings are consistent with the view that resource scarcity—rather than abundance-may drive conflict. ${ }^{18}$

While we believe the distinction between resource dependence (a flow variable) and abundance (a stock variable) is valuable, and that the proper treatment of endogeneity and reverse causality is essential, we do not view this as the definitive treatment on resources and conflict. Our preferred abundance variable is only available for up to 100 countries, and while it presents a nice combination of industrial and developing countries, we cannot rule out that the dataset suffers from selection bias (e.g., our natural capital measure may be easier to compute for more peaceful countries). Moreover, while we believe our abundance variable to be largely exogenous to conflict, by its nature it displays very little variation over time. We view this as an inevitable consequence of analysing resource abundance and attempting to tackle the endogeneity problem that compromises earlier work on time-variant flow variables. Nevertheless, we appreciate that our treatment of abundance in the core regressions represents an extreme perspective (indeed: the opposite extreme of the annual export, production or rent variables featuring in many panel studies). Importantly however, our main results appear robust with respect to time-varying oil production and reserves data, which also cover a wider range of countries and (conflict) episodes.

Two final remarks are in order. First, following most of the earlier work based on resource dependence, we have excluded some of the most contested resources.

\footnotetext{
${ }^{18}$ Our cross-national analysis questions whether there is a general tendency for resource-rich countries to be more conflict-prone, but we do not deny that natural resources played an important role within certain countries.
} 
In particular, secondary (lootable) diamonds are often implicated as a driver of conflict, but do not feature in our abundance variables. This is mainly for practical reasons-diamonds are also not included in the commonly used primary exports ratio variable, and therefore it appeared inappropriate to include diamond reserves as an instrument. Nevertheless, it is conceivable that (lootable) diamond reserves have a direct effect on the onset or duration of conflict, and we don't wish to downplay that possibility. Second, we have been silent on the exact mechanism linking resource abundance and higher incomes to a reduced risk of the onset of civil war. One interpretation is that the income of potential rebels is higher (or that the quality and quantity of public goods provided by the government improves-leader behaviour arguably matters; see Smith, 2004; or Caselli and Cunningham, 2009), raising the opportunity cost of rebellion. A competing hypothesis is that resource rents enable incumbent rulers to more effectively oppress rebellion (e.g., Azam and Mesnard, 2003). Our results therefore do not settle the greed versus grievance view on the resource-war link. Analysing this in more detail is left for future work.

\section{Supplementary material}

Supplementary material (the Appendix) is available online at the OUP website.

\section{Acknowledgements}

We thank three anonymous referees and Rick van der Ploeg for many helpful comments and suggestions. We also thank seminar participants at the University of Cambridge, University of Tilburg, the ETH Zurich, the University of Oxford (OxCarre launch meeting), IFPRI, and Imperial College for helpful comments. Remaining errors are our own.

\section{Funding}

Netherlands Organisation for Scientific Research (NWO) grant no 452-04333(EB).

\section{References}

Andre, C. and Platteau, J.P. (1998) Land relations under unbearable stress: Rwanda caught in the Malthusian Trap, Journal of Economic Behavior \& Organization, 34, 1-47.

Arezki, R. and van der Ploeg, R. (2007) Can the natural resource curse be turned into a blessing? Role of trade policies and institutions, Working Paper 07/55, International Monetary Fund, Washington, DC.

Auty, R. (2004) Natural resources and civil strife: a two-stage process, Geopolitics, 9, 29-49.

Azam, J.P. and Mesnard, A. (2003) Civil war and the social contract, Public Choice, 115, 455-75.

Ballantine, K. (2003) Beyond greed and grievance: reconsidering the economic dynamics of armed conflict, in K. Ballantine and J. Sherman (eds) The Political Economy of Armed Conflict: Beyond Greed and Grievance, Lynne Riener, London. 
Brunnschweiler, C.N. and Bulte, E.H. (2008) The resource curse revisited and revised: a tale of paradoxes and red herrings, Journal of Environmental Economics and Management, 55, 248-64.

Bulte, E.H., Damania, R., and Deacon, R.T. (2005) Resource intensity, institutions and development, World Development, 33, 1029-44.

Caselli, F. and Cunningham, T. (2009) Leader behavior and the natural resource curse, Oxford Economic Papers, doi:10.1093/oep/gpp023, Advance Access publication July 2009.

Collier, P. and Hoeffler, A. (1998) On economic causes of civil war, Oxford Economic Papers, 50, 563-73.

Collier, P. and Hoeffler, A. (2004) Greed and grievance in civil war, Oxford Economic Papers, 56, 563-95.

Collier, P. and Hoeffler, A. (2005) Resource rents, governance, and conflict, Journal of Conflict Resolution, 49, 625-33.

Collier, P., Hoeffler, A., and Rohner, D. (2009) Beyond greed and grievance: feasibility and civil war, Oxford Economic Papers, 61, 1-27.

De Soysa, I. (2002) Paradise is a bazaar? Greed, creed and governance in civil war 1989-1990, Journal of Peace Research, 39, 395-416.

De Soysa, I. and Neumayer, E. (2007) Resource wealth and the risk of civil war onset: results from a new data set of natural resource rents, 1970-1999, Conflict Management and Peace Science, 24, 201-18.

Ding, N. and Field, B.C. (2005) Natural resource abundance and economic growth, Land Economics, 81, 496-502.

Doyle, M. and Sambanis, N. (2000) International peace building: a theoretical and quantitative analysis, American Political Science Review, 94, 395-416.

Dunning, T. (2005) Resource dependence, economic performance, and political stability, Journal of Conflict Resolution, 49, 451-82.

Elbadawi, I. and Sambanis, N. (2002) How much war will we see? Explaining the prevalence of civil war, Journal of Conflict Resolution, 46, 307-34.

Fearon, J. (2004) Why do some civil wars last so much longer than others? Journal of Peace Research, 41, 275-301.

Fearon, J. (2005) Primary commodities exports and civil war, Journal of Conflict Resolution, 49, 483-507.

Fearon, J. and Laitin, D. (2003) Ethnicity, insurgency, and civil war, American Political Science Review, 97, 75-90.

Gleditsch, K.S. (2004) A revised list of wars between and within independent states, 1816-2002, International Interactions, 30, 231-62.

Gleditsch, N.P., Wallensteen, P., Eriksson, M., Sollenberg, M., and Strand, H. (2002) Armed conflict 1946-2001: a new dataset, Journal of Peace Research, 39, 615-37.

Grossman, H. (1991) A general equilibrium model of insurrections, American Economic Review, 81, 912-21.

Hirschleifer, J. (1995) Anarchy and its breakdown, Journal of Political Economy, 103, 26-52.

Homer-Dixon, T.F. (1999) Environment, Scarcity and Violence, Princeton University Press, Princeton, NJ. 
Humphreys, M. (2005) Natural resources, conflict, and conflict resolution: uncovering the mechanisms, Journal of Conflict Resolution, 49, 508-37.

Isham, J., Woolcock, M., Pritchett, L., and Busby, G. (2005) The varieties of resource experience: resource export structures and the political economy of economic growth, World Bank Economic Review, 19, 141-74.

Jensen, N. and Wantchekon, L. (2004) Resource wealth and political regimes in Africa, Comparative Political Studies, 37, 816-41.

Le Billon, P. (2001) The political ecology of war: natural resources and armed conflicts, Political Geography, 20, 561-84.

Leite, C. and Weidmann, J. (2002) Does Mother Nature corrupt? Natural resources, corruption and economic growth, in G. Abed and S. Gupta (eds) Governance, Corruption, and Economic Performance, International Monetary Fund, Washington, DC.

Lujala, P. (2009) The spoils of nature: armed civil conflict and rebel access to natural resources, Journal of Peace Research, forthcoming.

Lujala, P., Gleditsch, N.P., and Gilmore, E. (2005) A diamond curse? Civil war and a lootable resource, Journal of Conflict Resolution, 49, 538-62.

Mehlum, H., Moene, K., and Torvik, R. (2006) Institutions and the resource curse, Economic Journal, 116, 1-20.

Murshed, M. and Tadjoeddin, Z. (2007) Reappraising the greed and grievance explanations for violent internal conflict, MICROCON Research Working Paper 2, MICROCON, Brighton.

Norman, C.S. (2009) Rule of law and the resource curse: abundance versus intensity, Environmental and Resource Economics, 43, 183-207.

Olsson, O. (2006) Conflict diamonds, Journal of Development Economics, 82, 267-86.

Persson, T. and Tabellini, G. (2003) The Economic Effects of Constitutions, MIT Press, Cambridge MA.

Regan, A. (2003) The Bouganville conflict: political and economic agendas, in K. Ballantine and J. Sherman (eds) The Political Economy of Armed Conflict: Beyond Greed and Grievance, Lynne Riener, London.

Reynal-Querol, M. (2002) Ethnicity, political systems, and civil wars, Journal of Conflict Resolution, 46, 29-54.

Ron, J. (2005) Paradigm in distress: primary commodities and civil war, Journal of Conflict Resolution, 49, 443-50.

Ross, M.L. (2001) Does oil hinder democracy? World Politics, 53, 325-61.

Ross, M.L. (2003) Oil, drugs and barons: the varying role of natural resources in violent conflict, in K. Ballantine and J. Sherman (eds) The Political Economy of Armed Conflict: Beyond Greed and Grievance, Lynne Riener, London.

Ross, M.L. (2004a) What do we really know about natural resources and civil war? Journal of Peace Research, 41, 337-56.

Ross, M.L. (2004b) How do natural resources influence civil war? Evidence from 13 cases, International Organisation, 58, 35-68.

Ross, M. (2006) A closer look at oil, diamonds, and civil war, Annual Review of Political Science, 9, 265-300. 
Rosser, A. (2006) The political economy of the resource curse: a literature survey, IDS Working Paper 268, Institute of Development Studies, Brighton.

Sachs, J.D and Warner, A.M. (1997) Natural resource abundance and economic growth, Working Paper, CID and Harvard Institute for International Development, Cambridge, MA.

Sachs, J.D. (2003) Institutions don't rule: Direct effects of geography on per capita income, NBER Working Paper No. 9490, National Bureau of Economic Research, Cambridge MA.

Smith, B. (2004) Oil wealth and regime survival in the developing world, 1960-1999, American Journal of Political Science, 48, 232-46.

Snyder, R. and Bhavnani, R. (2005) Diamonds, blood and taxes: a revenue-centered framework for explaining social order, Journal of Conflict Resolution, 49, 563-97.

Van der Ploeg, F. (2009) Challenges and opportunities for resource rich economies, Journal of Economic Literature, forthcoming.

World Bank (1997) Expanding the measure of wealth: indicators of environmentally sustainable development, Environmentally Sustainable Development Studies and Monographs Series no. 17.

World Bank (2006) Where is the wealth of nations? Measuring capital for the $21^{\text {st }}$ century, World Bank, Washington, DC. 